IZA DP No. 7584

Geographic Differences in the Earnings of Economics Majors

John V. Winters

Weineng Xu

August 2013

Forschungsinstitut zur Zukunft der Arbeit Institute for the Study of Labor 


\title{
Geographic Differences in the Earnings of Economics Majors
}

\author{
John V. Winters \\ Oklahoma State University \\ and $I Z A$ \\ Weineng $\mathrm{Xu}$ \\ University of Arkansas

\section{Discussion Paper No. 7584 \\ August 2013} \\ IZA \\ P.O. Box 7240 \\ 53072 Bonn \\ Germany \\ Phone: +49-228-3894-0 \\ Fax: +49-228-3894-180 \\ E-mail: iza@iza.org
}

Any opinions expressed here are those of the author(s) and not those of IZA. Research published in this series may include views on policy, but the institute itself takes no institutional policy positions. The IZA research network is committed to the IZA Guiding Principles of Research Integrity.

The Institute for the Study of Labor (IZA) in Bonn is a local and virtual international research center and a place of communication between science, politics and business. IZA is an independent nonprofit organization supported by Deutsche Post Foundation. The center is associated with the University of Bonn and offers a stimulating research environment through its international network, workshops and conferences, data service, project support, research visits and doctoral program. IZA engages in (i) original and internationally competitive research in all fields of labor economics, (ii) development of policy concepts, and (iii) dissemination of research results and concepts to the interested public.

IZA Discussion Papers often represent preliminary work and are circulated to encourage discussion. Citation of such a paper should account for its provisional character. A revised version may be available directly from the author. 
IZA Discussion Paper No. 7584

August 2013

\section{ABSTRACT}

\section{Geographic Differences in the Earnings of Economics Majors}

Economics has been shown to be a relatively high earning college major, but geographic differences in earnings have been largely overlooked. This paper uses the American Community Survey to examine geographic differences in both absolute earnings and relative earnings for economic majors. We find that there are substantial geographic differences in both the absolute and relative earnings of economics majors even controlling for individual characteristics such as age and advanced degrees. We argue that mean earnings in specific labor markets are a better measure of the benefits of majoring in economics than simply looking at national averages.

JEL Classification: $\quad$ I23, J24, J31, R23

Keywords: economics major, earnings differentials, college education, local labor markets

Corresponding author:

John V. Winters

Oklahoma State University

Department of Economics

Spears School of Business

Stillwater, OK 74074

USA

E-mail: jvwinte@okstate.edu 


\section{INTRODUCTION}

Economists argue that students interested in pursuing a college education weigh the costs and benefits of doing so. The various costs and benefits are well documented. The costs typically include tuition and fees, room and board, expenditures on textbooks and supplies, and the opportunity cost of the student's time including the foregone earnings that a student could have earned had they gone to work instead of college. There are a number of non-pecuniary benefits from gaining a college education, but for most students the primary benefit is the higher future earnings that they expect to receive after completing a degree. ${ }^{1}$ However, the extent to which a college education increases future earnings depends very heavily on the field of study in which a student decides to major (Rumberger and Thomas 1993; Montmarquette, Cannings, and Mahseredjian 2002; Freeman and Hirsch 2008). Some majors offer very high earnings while others offer much lower earnings.

Previous researchers have documented that economics is a relatively high earning college major in the United States (Black, Sanders, and Taylor 2003; Allgood et al. 2011; Altonji, Blom and Meghir 2012). This is true both for recent graduates and for workers several years after graduation. Chevalier (2011) also reports economics to be a relatively high earning major in the United Kingdom. For Canada, though, Finnie and Frennette (2003) find that earnings for economics majors are similar to the average earnings of other majors. Allgood et al. (2011, 2012) also report differences between economics and non-economics majors for a variety of other outcomes including self-employment, graduate degrees, home equity, savings, investment decisions, retirement plans, and civic behaviors.

\footnotetext{
${ }^{1}$ In addition to higher future earnings, other benefits of a college education include better future health (Eide and Showalter 2011), opportunities to meet higher ability potential spouses (Becker 1973; Lefgren and McIntyre 2006), and the consumption value of education itself (Alstadsæter 2011).
} 
Studies interested in earnings differences by college major typically use national data and do not look at earnings differences for specific geographic areas. This is largely because the typical datasets that have been used do not provide detailed information on earnings by college major and geographic area. Furthermore, the surveys used typically have relatively small samples, so that even if detailed information on college major and geographic area are available, the number of economics majors in a given geographic area in the sample is too small to produce precise estimates of geographic differences. However, there are important differences in the earnings of economics majors across geographic areas that have been largely overlooked. ${ }^{2}$ Many students intend to work in a particular state or metropolitan area after college and national average salaries by college major may not be very informative for them. Geographically constrained students considering majoring in economics are likely more interested in the earnings of economics majors in the labor market(s) in which they intend to work. Furthermore, some recent economics graduates do have flexibility to choose a particular state or metropolitan area in which to start their careers but have limited information on the average salaries they can expect to earn in different locations with a degree in economics. In 2009 the American Community Survey (ACS) introduced a new question that asks college graduates to report the undergraduate field in which they majored. The ACS is a large survey conducted by the U.S. Census Bureau and includes geographic identifiers for state and metropolitan area. The ACS, therefore, now makes it possible to examine geographic differences in earnings for specific college majors. Altonji et al.

\footnotetext{
${ }^{2}$ There is a separate literature that investigates geographic differences in earnings more generally (e.g. DuMond, Hirsch, and Macpherson 1999; Glaeser and Maré 2001; Yankow 2006; Winters 2009), but that literature has not examined geographic differences for specific college majors.
} 
(2012) use the ACS to examine earnings differences by college major but they do not examine geographic differences.

This paper uses the ACS to estimate geographic differences in both the absolute and and relative earnings of economics majors. Absolute earnings differences are computed based on geographic differences among economics majors. These provide insight into what a given economics major might earn by working in a different labor market. Relative earnings are computed relative to the earnings of non-economics majors in the same labor market. Relative earnings shed light on the higher earnings that could be achieved by majoring in economics conditional on working in a particular labor market. We find that there are considerable geographic differences in both absolute and relative earnings. We are unable to fully account for potential issues with selection, and thus our results should not be interpreted as causal. However, we offer a novel descriptive analysis that has not previously been possible. We hope that this new information allows geographically constrained students to make more informed decisions about their college majors and allows geographically mobile economics graduates to make more informed decisions about where to start their careers.

\section{THE DATA AND SUMMARY STATISTICS}

This research uses the 2009 and 2010 American Community Survey (ACS), both of which are one percent samples of the U.S. population. We obtain the data from the Integrated Public Use Microdata Series USA (IPUMS USA), created and maintained by Ruggles et al. (2010). The ACS includes individual information on geographic location, earned income, education, and demographic characteristics. The 2009 ACS was the first year to collect information on college major for college graduates and at the time this paper was written data for the 2011 ACS had not 
yet been released, so we only use the 2009 and 2010 ACS. Earnings in the 2009 ACS are converted to year 2010 dollars using the Consumer Price Index. We restrict our sample to persons between ages 22 and 61 that have completed a bachelor's degree or higher, are not currently in school, had positive earned income in the prior twelve months, and worked in the U.S. during the week prior to the survey. ${ }^{3}$ We also exclude observations with imputed data for earnings or college major.

Table 1 reports mean annual earnings by college major ranked from highest to lowest and also reports the share of all college graduates majoring in each field. We treat both economics majors and business economics majors as economics majors. We also group some of the other detailed majors into slightly broader categories (e.g. we combine history and U.S. history majors into one group). We end up with 147 detailed college major fields. Economics majors rank near the top of the list. With mean annual earnings of $\$ 116,133$, economics ranks fourth behind only pre-med, math/computer science, and actuarial science, all of which are fairly small majors. Economics majors have higher mean earnings than engineers, biologists, and other disciplines in business and the social sciences. On average, economics is a very financially rewarding college major. However, there are likely important geographic differences in the earnings of economics majors.

The geographic variables in the ACS include the state and the metropolitan area in which individuals reside and work. Since we are interested in income earned from working, our analysis defines locations based on where individuals work. We conduct separate analyses for states and metropolitan areas. The lowest level of identifiable

\footnotetext{
${ }^{3}$ In results not shown we also explored the effects of restricting the sample to persons with only a bachelor's degree. Doing so does not qualitatively alter the qualitative results in this study. These results are available by request.
} 
geography in the publicly available ACS data is a sub-state area referred to as a PUMA (Public Use Microdata Area). For some respondents, the PUMA in which they work overlaps a metropolitan area and a non-metropolitan area, and Census confidentiality procedures prevent us from knowing exactly where they work. We exclude this small group of individuals from the metropolitan area analysis since their work location is unknown. However, PUMAs do not cross states so states are perfectly identified and these individuals are included in the state analysis.

Because only relatively large metro areas have a sufficiently large number of economics majors to compute fairly precise coefficient estimates, we combine small and mid-size metropolitan areas into several groups. More specifically, we rank metropolitan areas by the number of college graduates working in each. We define the 50 metros with the most college graduates as large, the next 50 as mid-size, and the remaining metros as small. The sample also includes persons working in non-metropolitan areas. Using these definitions 63.9 percent of our metro sample work in large metro areas, 11.7 percent work in mid-size metros, 12.6 percent work in small metros, and 11.8 percent work in non-metropolitan areas. We further divide the mid-size, small, and non-metropolitan areas by Census region (Northeast, Midwest, South, and West) resulting in 12 metro/non-metro groups. Each of the fifty large metro areas is treated as its own group giving us a total of 62 geographic groups for our metro analysis.

Tables 2 and 3 present mean values for some important variables for each state (Table 2) and each metro area/group (Table 3). These include mean real earnings for economics majors, mean real earnings for non-economics majors, relative earnings of economics majors, and the percentage of college graduates working in the area that majored in economics. There are considerable geographic differences in the mean earnings of economics majors with more densely populated areas tending to have much higher earnings. New York State and New York 
$\mathrm{MSA}^{4}$ (Metropolitan Statistical Area) stand out for several reasons and will be used as the base groups in our regression analysis that looks at geographic differences in absolute earnings among economics majors. First, New York City is the nation's financial capital and also its largest city. As a result, New York State and New York MSA have by far the highest mean earnings for economics majors at $\$ 167,634$ and $\$ 170,234$. These are more than twice as large as mean earnings in several states and metro areas/groups. New York MSA also has a higher percentage (4.4 percent) of economics majors than any other metro area, and New York State is second only to the District of Columbia among states (D.C. is not an actual state but is treated as such in our analysis).

Geographic areas with high mean earnings for economics majors also tend to have high earnings for non-economics majors. Consistent with previous literature on geographic differences in earnings (e.g., DuMond, Hirsch, and Macpherson 1999; Glaeser and Maré 2001; Yankow 2006; Winters 2009), earnings for both economics and non-economics majors tend to be higher in large densely populated states and metropolitan areas with high costs of living. Thus, persons interested in geographic differences in the earnings of economics majors may be primarily interested in the relative earnings of economics majors, that is, how earnings for economics majors compare to non-economics majors in the same geographic area. ${ }^{5}$ One way to measure relative earnings that is reported in Tables 2 and 3 is to divide mean earnings for economics majors by mean earnings for non-economics majors. Most states and

\footnotetext{
${ }^{4}$ We reference MSAs by their primary core city, though the official names often include other smaller cities in the metropolitan area.

${ }^{5}$ A considerably more complicated alternative to examining earnings relative to non-economics majors is to construct a cost of living index for each geographic area and assess the value of each area's location specific amenities. One could then compute a "real wage" for economics majors in each area. Winters (2009) reports a cost of living index available for use but valuing location specific amenities is considerably more subjective.
} 
metropolitan areas/groups have relative earnings ratios greater than one because economics majors typically out-earn non-economics majors. However, there is wide variation in the relative earnings for economic majors across geographic areas. New York State and New York MSA have relative earnings for economics majors of 1.89 and 1.77 , the second highest among states (surprisingly behind Wyoming) and the third highest among the metro groups (behind St. Louis MSA and the Northeastern mid-size metro group).

Tables 2 and 3 also report the percentage of college graduates in each area that majored in economics. Economic theory suggests that higher relative earnings will make economics a more desirable major and increase the percentage who major in economics. A rigorous analysis is beyond the scope of our study, but the simple correlation between relative earnings and the percentage of economics majors is 0.24 for states in Table 2 and 0.09 for metro areas in Table 3. Interestingly, the correlation between the percentage of economics majors and mean earnings for economics majors is much higher at 0.70 in Table 2 and 0.62 in Table 3 . In results not shown, we also found similar relationships measuring the percentage of economics majors using institutional degree conferral surveys from the Integrated Postsecondary Education Data System (IPEDS); the state correlation is 0.15 with relative earnings and 0.47 with mean earnings for economics majors.

\section{REGRESSION FRAMEWORK}

The information in Tables 2 and 3 clearly illustrates geographic differences in earnings for economics majors both among economics majors and relative to non-economics majors in the same geographic area. However, looking at mean earnings does not account for the fact that workers also differ across areas in individual characteristics such as sex, race/ethnicity, and 
advanced degrees. The regression analysis below controls for these. Areas also differ in the mix of occupations and industries that they offer and this could affect salaries. However, the mix of occupations and industries is in many ways part of what an area offers to its residents, so controlling for industry and occupation may inappropriately net out some of the wage premium that an area offers. Therefore, we present regression results both without and with controls for occupation and industry. However, there is still some concern that individuals select into majors, locations, and the workforce based on unobservable characteristics and omitted variables. The regression results, therefore, should still be interpreted as descriptive and not necessarily causal.

The dependent variable for the regression analysis is log real annual earnings. We first examine geographic differences in absolute earnings. This analysis restricts the sample to economics majors and regresses log real annual earnings for person $i$ in geographic area $g$ on a set of geographic (state or metro) dummies and set of dummies for individual characteristics:

$$
\ln \left(\text { Earnings }_{i g}\right)=\Gamma_{g}+\beta X_{i g}+\varepsilon_{i g}
$$

The individual characteristics in $X$ include dummy variables for age, sex, race, Hispanic origin, foreign born status, highest degree completed, and in some cases occupation and industry. Our interest is in the $\Gamma$ coefficients for the geographic dummies. These can be interpreted as geographic differences in log annual earnings for economics majors. New York State and New York MSA are the omitted base groups for the state and metro analyses, so geographic differences are measured relative to them. ${ }^{6}$

We next use regression analysis to examine geographic differences in relative earnings of economics majors. This analysis includes both economics and non-economics majors and

\footnotetext{
${ }^{6}$ Making these the omitted base groups also produces much more precise $\Gamma$ estimates than would result if the omitted groups were areas with relatively few economics majors.
} 
estimates a separate regression for each state and each metropolitan area/group. For each geographic area we regress log real annual earnings on the individual characteristics above and a dummy variable for being an economics major:

$$
\ln \left(\text { Earnings }_{i g}\right)=\beta_{g} X_{i g}+\theta_{g} \text { ECONMAJOR }_{i g}+\mu_{i g}
$$

Both $\beta_{g}$ and $\theta_{g}$ are allowed to vary across geographic areas. The coefficients in $\theta_{g}$ measure the log earnings premium received by economic majors relative to non-economics majors working in the same geographic area. Some states are likely to have high relative earnings for economics majors while others have low relative earnings.

One final issue is that the composition of college majors differs across geographic areas, which alters the non-economics comparison group. Some places have a high percentage of majors with high mean earnings while others have more persons with majors with relatively low earnings. To account for this we reweight individual observations so that the composition of non-economics majors in each state or metro area is the same as their shares in the national workforce. This procedure uses separate weights for the state and metro analyses. The reweighting, therefore, makes the non-economics comparison group equivalent across areas. We did estimate the regressions without reweighting, and the results were generally similar to those below but there were some moderate differences. Reweighting is the preferred method, so we do not report results without reweighting.

\section{REGRESSION RESULTS}

\section{Geographic Differences in Absolute Earnings among Economics Majors}

We first discuss the geographic differences in absolute earnings among economics majors. Absolute earnings differences offer insight into what an economics major working in one area 
might earn by working in a different area. Table 4 presents regression results for the state analysis. New York is the omitted base group. We report results without and with controls for occupation and industry since the mix of jobs and industries is a potentially important driver of earnings differences across states. ${ }^{7}$ However, adding occupation and industry controls has only a moderate effect on the results for absolute earnings differences. All of the state dummy coefficients are negative, meaning that New York still has the highest absolute earnings for economics majors even after controlling for observable individual characteristics. The coefficients are statistically significant for all but two states (D.C. and Wyoming) in the specification without occupation and industry and significant for all but four states (D.C., Idaho, West Virginia, and Wyoming) with occupation and industry controls. Other states with relatively high earnings for economics majors include Connecticut, California, New Jersey, Illinois, and Massachusetts. Large and densely populated states, therefore, tend to have higher earnings. ${ }^{8}$ States with low earnings for economics majors are typically small and have low population density such as South Dakota, Iowa, Vermont, Alaska, Montana, and New Hampshire.

Table 5 presents regression results for the metropolitan area analysis. New York MSA is the omitted base group. All of the metro dummy coefficients are negative and all are statistically significant except for San Jose without controls for occupation and industry. New York still has the highest mean earnings for economics majors among the metro areas/groups even controlling for individual characteristics. Others with relatively high earnings include San Francisco,

\footnotetext{
${ }^{7}$ We use 83 dummies for occupation and 16 dummies for industry. Additional groupings provided similar results.

${ }^{8}$ A few smaller states have relatively large coefficients but have small samples of economics majors and are not precisely estimated. For example, Wyoming is the least populous state in the U.S. and has only seven observations in our sample who are economics majors causing its coefficient estimate to be very imprecisely estimated.
} 
Boston, Los Angeles, and Chicago. The lowest earnings for economics majors are found in the non-metropolitan area groups, West Palm Beach, Greensboro, Oklahoma City, and Memphis.

\section{Geographic Differences in Relative Earnings for Economics Majors}

Relative earnings offer insight into the benefits of majoring in economics conditional on working in a given geographic area. For the state analysis in Table 4, the economics major coefficient is statistically significantly positive for only 22 of the 51 states when we exclude occupation and industry; including these controls reduces the number of significant coefficients to 15 . Some states have relatively large coefficients that are imprecisely estimated due to the relatively small number of economics majors in the sample in those states, but many states have coefficients that are close to zero or even negative, though none are significantly negative. Thus, economics does not seem to be an especially financially rewarding major for students planning to work in states such as New Hampshire, Alaska, Iowa, or even Florida. However, economics majors in New York enjoy a log earnings premium of 0.434 without controlling for occupation and industry and 0.237 with these additional controls. Thus, even controlling for individual characteristics economics majors working in New York do quite well relative to non-economics majors. Other states with strongly positive relative earnings coefficients include California, Connecticut, Idaho, Illinois, Massachusetts, Minnesota, Missouri, New Jersey, Pennsylvania, Texas, and Washington. However, there is some difference in coefficients with and without the occupation and industry controls.

For the metro analysis in Table 5, the economics major coefficients are statistically significantly positive for 31 of the 62 metropolitan areas/groups without occupation and industry controls and significant for 23 areas with the additional controls. Several areas have 
insignificant coefficients that are negative or close to zero. The lowest relative earnings coefficients are in areas such as Memphis, West Palm Beach, Oklahoma City, Greensboro, and the Southern non-metropolitan group. Areas with the highest relative earnings coefficients include the Northeastern mid-size metro group, New York, Chicago, Louisville, Boston, Seattle, and San Francisco, though there are again some differences in coefficients with and without the occupation and industry controls. ${ }^{9}$

\section{CONCLUSION}

Earnings differences across college majors provide important signals for young people pursuing higher education. While there are important non-monetary factors affecting college major choices, potential earnings certainly play an important role. Economics majors have relatively high earnings, which may partially explain the major's relatively high popularity. However, there are considerable geographic differences in the earnings of economics majors. New York State has the highest mean earnings for economics majors among states and New York MSA has the highest mean earnings for economics majors among metropolitan areas, both with mean earnings twice as large as in several other areas. More generally, high earnings for economics majors are found in densely populated areas such as Chicago, Boston, and San Francisco. The lowest earnings are typically in less populated and lower density areas. These results are also generally true even controlling for individual characteristics and measuring earnings relative to those of non-economics majors, though there are some exceptions.

\footnotetext{
${ }^{9}$ The high relative earnings for the Northeastern mid-size metropolitan group may partially result from proximity to New York. The Northeastern mid-size metropolitan group includes the following metropolitan areas: Allentown, PA; Harrisburg, PA; Monmouth, NJ; New Haven, CT; Portland, ME; Providence, RI; Scranton, PA; Springfield, MA; Stamford, CT; Syracuse, NY; Trenton, NJ.
} 
Students considering choosing economics as a major should not base their decision solely on the average earnings for economics majors in the U.S. Instead, a more informed decision can be made based on the earnings of economics majors in the labor market(s) in which a student expects to work. Until recently reliable earnings information by college major and geographic area has been quite scarce. However, with the recent addition of college major information to the American Community Survey, reliable earnings information by college major and geographic area can now be obtained. Disseminating this information has the potential to help students make more informed decisions both about their college major and about the geographic area in which to start their careers after they have chosen a major. Furthermore, while this paper focuses on geographic differences in the earnings of economics majors, the ACS can also be used to estimate geographic earnings differences in other popular majors and this is a useful exercise for future research. 


\section{REFERENCES}

Allgood, S., W. Bosshardt, W. van der Klaauw, and M. Watts. 2011. Economics coursework and long-term behavior and experiences of college graduates in labor markets and personal finance. Economic Inquiry 49(3): 771-794.

Allgood, S., W. Bosshardt, W. van der Klaauw, and M. Watts. 2012. Is economics coursework, or majoring in economics, associated with different civic behaviors? The Journal of Economic Education 43(3): 248-268.

Alstadsæter, A. 2011. Measuring the consumption value of higher education. CESifo Economic Studies 57(3): 458-479.

Altonji, J., E. Blom and C. Meghir. 2012. Heterogeneity in human capital investments: High school curriculum, college major, and careers. Annual Review of Economics 4: 185-223.

Becker, G.S. 1973. A theory of marriage: Part I. Journal of Political Economy 81(4): 813-846.

Black, D.A., S. Sanders, and L. Taylor. 2003. The economic reward for studying economics. Economic Inquiry 41(3): 365-377.

Chevalier, A. 2011. Subject choice and earnings of UK graduates. Economics of Education Review 30(6): 1187-1201.

DuMond, J.M., B.T. Hirsch, and D.A. Macpherson. 1999. Wage differentials across labor markets and workers: Does cost of living matter? Economic Inquiry 37(4): 577-598.

Eide, E.R., and M.H. Showalter. 2011. Estimating the relation between health and education: What do we know and what do we need to know? Economics of Education Review 30(5): 778-791. 
Finnie, R. and M. Frenette. 2003. Earning differences by major field of study: Evidence from three cohorts of recent Canadian graduates. Economics of Education Review 22(2): 179192.

Freeman, J.A. and B.T. Hirsch. 2008. College majors and the knowledge content of jobs. Economics of Education Review 27(5): 517-535.

Glaeser, E.L. and D.C. Maré. 2001. Cities and skills. Journal of Labor Economics 19(2): 316342.

Lefgren, L. and F. McIntyre. 2006. The relationship between women's education and marriage outcomes. Journal of Labor Economics 24(4): 787-830.

Montmarquette, C., K. Cannings, and S. Mahseredjian. 2002. How do young people choose college majors? Economics of Education Review 21(6): 543-556.

Ruggles, S., J.T. Alexander, K. Genadek, R. Goeken, M.B. Schroeder, and M. Sobek. 2010. Integrated Public Use Microdata Series: Version 5.0 [Machine-readable database]. Minneapolis: University of Minnesota.

Rumberger, R.W. and S.L. Thomas. 1993. The economic returns to college major, quality and performance: A multilevel analysis of recent graduates. Economics of Education Review 12(1): 1-19.

Winters, J.V. 2009. Wages and Prices: Are workers fully compensated for cost of living differences? Regional Science and Urban Economics 39(5): 632-643.

Yankow, J.J. 2006. Why do cities pay more? An empirical examination of some competing theories of the urban wage premium. Journal of Urban Economics 60(2): 139-161. 
Table 1: Mean Earnings by College Major Field

\begin{tabular}{|c|c|c|c|}
\hline $\begin{array}{l}\text { Earnings } \\
\text { Rank }\end{array}$ & College Major Field & $\begin{array}{c}\text { Mean } \\
\text { Earnings }\end{array}$ & $\begin{array}{c}\% \text { of College } \\
\text { Graduates }\end{array}$ \\
\hline 1 & Health and Medical Preparatory Programs & 162,619 & 0.15 \\
\hline 2 & Mathematics and Computer Science & 121,352 & 0.02 \\
\hline 3 & Actuarial Science & 118,109 & 0.03 \\
\hline 4 & Economics & 116,133 & 2.28 \\
\hline 5 & Zoology & 114,685 & 0.24 \\
\hline 6 & Chemical Engineering & 114,099 & 0.58 \\
\hline 7 & Chemistry & 110,608 & 1.11 \\
\hline 8 & Miscellaneous Engineering & 107,599 & 0.41 \\
\hline 9 & Pharmacy, Pharmaceutical Sciences, and Admin. & 107,589 & 0.53 \\
\hline 10 & Electrical Engineering & 106,953 & 2.12 \\
\hline 11 & Aerospace Engineering & 105,783 & 0.21 \\
\hline 12 & Physics & 104,791 & 0.53 \\
\hline 13 & Biology & 103,523 & 3.48 \\
\hline 14 & Mechanical Engineering & 102,237 & 1.70 \\
\hline 15 & Statistics and Decision Science & 100,576 & 0.08 \\
\hline 16 & Materials Science & 99,443 & 0.02 \\
\hline 17 & Astronomy and Astrophysics & 99,147 & 0.02 \\
\hline 18 & Political Science and Government & 97,742 & 2.49 \\
\hline 19 & Finance & 97,269 & 2.15 \\
\hline 20 & Industrial and Manufacturing Engineering & 96,842 & 0.40 \\
\hline 21 & Civil Engineering & 96,419 & 1.00 \\
\hline 22 & Molecular Biology & 95,549 & 0.11 \\
\hline 23 & General Engineering & 94,240 & 1.11 \\
\hline 24 & Microbiology & 93,780 & 0.25 \\
\hline 25 & Pharmacology & 93,122 & 0.02 \\
\hline 26 & Mathematics & 92,800 & 1.32 \\
\hline 27 & Materials Engineering and Materials Science & 92,520 & 0.08 \\
\hline 28 & Computer Engineering & 92,460 & 0.47 \\
\hline 29 & International Relations & 90,233 & 0.26 \\
\hline 30 & Accounting & 89,661 & 4.17 \\
\hline 31 & Computer Science & 89,352 & 2.21 \\
\hline 32 & Agricultural Economics & 87,397 & 0.10 \\
\hline 33 & Construction Services & 87,149 & 0.18 \\
\hline 34 & Geology and Earth Science & 86,510 & 0.38 \\
\hline 35 & Miscellaneous Social Sciences & 86,488 & 0.06 \\
\hline 36 & Physiology & 86,293 & 0.17 \\
\hline 37 & Cognitive Science and Biopsychology & 84,633 & 0.02 \\
\hline 38 & Neuroscience & 83,958 & 0.03 \\
\hline 39 & General Business & 83,009 & 3.97 \\
\hline 40 & History & 82,421 & 2.07 \\
\hline 41 & Engineering and Industrial Management & 82,131 & 0.30 \\
\hline 42 & Management Info Systems and Statistics & 81,255 & 0.41 \\
\hline 43 & Military Technologies & 81,236 & 0.01 \\
\hline 44 & Public Administration & 80,861 & 0.22 \\
\hline 45 & Operations, Logistics and E-Commerce & 80,143 & 0.14 \\
\hline 46 & Transportation Sciences and Tech & 79,997 & 0.29 \\
\hline 47 & Multi-disciplinary or General Science & 79,579 & 0.44 \\
\hline 48 & Biological Engineering & 79,471 & 0.10 \\
\hline 49 & Physical Sciences & 78,197 & 0.03 \\
\hline 50 & Interdisciplinary and Multi-Disciplinary Studies & 75,694 & 0.68 \\
\hline 51 & Oceanography & 75,588 & 0.04 \\
\hline 52 & Atmospheric Sciences and Meteorology & 75,481 & 0.05 \\
\hline 53 & Miscellaneous Biology & 74,996 & 0.13 \\
\hline
\end{tabular}




\begin{tabular}{|c|c|c|c|}
\hline 54 & Architecture & 74,833 & 0.76 \\
\hline 55 & Business Management and Administration & 74,567 & 7.17 \\
\hline 56 & Industrial and Organizational Psychology & 74,294 & 0.05 \\
\hline 57 & Philosophy and Religious Studies & 74,234 & 0.66 \\
\hline 58 & Marketing and Marketing Research & 73,810 & 2.52 \\
\hline 59 & Electrical Engineering Technology & 73,644 & 0.22 \\
\hline 60 & Miscellaneous Engineering Tech & 73,556 & 0.24 \\
\hline 61 & Information Sciences & 72,598 & 0.38 \\
\hline 62 & Area, Ethnic, and Civilization Studies & 72,484 & 0.31 \\
\hline 63 & Forestry & 71,917 & 0.16 \\
\hline 64 & Computer and Information Systems & 71,350 & 0.66 \\
\hline 65 & Miscellaneous Agriculture & 71,097 & 0.10 \\
\hline 66 & Other Foreign Languages & 70,756 & 0.14 \\
\hline 67 & Mechanical Engineering Related Tech & 69,740 & 0.08 \\
\hline 68 & Human Resources and Personnel Management & 69,635 & 0.45 \\
\hline 69 & International Business & 69,528 & 0.20 \\
\hline 70 & Miscellaneous Business and Medical Admin & 69,151 & 0.21 \\
\hline 71 & Miscellaneous Psychology & 67,940 & 0.12 \\
\hline 72 & Health and Medical Administrative Services & 67,808 & 0.24 \\
\hline 73 & Geography & 67,305 & 0.31 \\
\hline 74 & Agriculture Production and Management & 67,291 & 0.23 \\
\hline 75 & Medical Technologies Technicians & 66,831 & 0.39 \\
\hline 76 & English Language and Literature & 66,541 & 2.84 \\
\hline 77 & Nursing & 65,996 & 3.67 \\
\hline 78 & Journalism & 65,620 & 1.03 \\
\hline 79 & Humanities & 65,347 & 0.11 \\
\hline 80 & Pre-Law and Legal Studies & 65,172 & 0.14 \\
\hline 81 & Plant Science and Agronomy & 64,905 & 0.21 \\
\hline 82 & Educational Administration and Supervision & 64,864 & 0.10 \\
\hline 83 & General Medical and Health Services & 64,632 & 0.26 \\
\hline 84 & French, German, Latin and Other Foreign Language & 64,215 & 0.63 \\
\hline 85 & General Agriculture & 64,146 & 0.24 \\
\hline 86 & Anthropology and Archeology & 63,814 & 0.42 \\
\hline 87 & Botany & 63,508 & 0.06 \\
\hline 88 & Computer Networking and Telecommunications & 63,486 & 0.14 \\
\hline 89 & Linguistics and Comparative Language and Literature & 63,456 & 0.18 \\
\hline 90 & General Social Sciences & 62,988 & 0.28 \\
\hline 91 & Communications & 62,763 & 2.32 \\
\hline 92 & Natural Resources Management & 62,635 & 0.22 \\
\hline 93 & Liberal Arts & 62,633 & 1.36 \\
\hline 94 & Psychology & 62,224 & 4.34 \\
\hline 95 & Animal Sciences & 61,800 & 0.28 \\
\hline 96 & Intercultural and International Studies & 61,621 & 0.15 \\
\hline 97 & Court Reporting & 61,574 & 0.01 \\
\hline 98 & Environmental Science & 61,270 & 0.30 \\
\hline 99 & Nuclear, Industrial Radiology, and Biological Tech & 61,220 & 0.03 \\
\hline 100 & Art History and Criticism & 60,759 & 0.22 \\
\hline 101 & Treatment Therapy Professions & 60,468 & 0.74 \\
\hline 102 & Precision Production and Industrial Arts & 60,451 & 0.01 \\
\hline 103 & Criminal Justice and Fire Protection & 60,417 & 1.73 \\
\hline 104 & Nutrition Sciences & 59,439 & 0.17 \\
\hline 105 & Criminology & 59,116 & 0.16 \\
\hline 106 & Sociology & 58,740 & 1.61 \\
\hline 107 & Hospitality Management & 58,588 & 0.40 \\
\hline 108 & Medical Assisting Services & 57,938 & 0.15 \\
\hline 109 & Advertising and Public Relations & 57,690 & 0.42 \\
\hline
\end{tabular}


Electrical and Mechanic Repairs and Tech

53,705

52,938

Education

52,255

Special Needs Education

51,638

Physical Fitness, Parks, Recreation, and Leisure

51,574

Cosmetology Services and Culinary Arts

51,494

51,211

50,817

General Education

50,376

Music

50,330

Language and Drama Education

Commercial Art and Graphic Design

50,161

Fine Arts

Art and Music Education

49,630

48,656

48,574

47,723

Drama and Theater Arts

47,433

Counseling Psychology

46,090

Social Work

139

Family and Consumer Sciences

Elementary Education

45,488

45,421

44,806

44,262

42,110

40,244

0.52

Theology and Religious Vocations

39,883

0.03

0.22

0.05

0.57

Human Services and Community Organization 
Table 2: State Means for Selected Variables

\begin{tabular}{|c|c|c|c|c|}
\hline State & $\begin{array}{c}\text { Mean Real Earnings } \\
\text { for Economics } \\
\text { Majors }\end{array}$ & $\begin{array}{c}\text { Mean Real Earnings } \\
\text { for Non-Economics } \\
\text { Majors }\end{array}$ & $\begin{array}{c}\text { Relative Earnings } \\
\text { of Economics } \\
\text { Majors }\end{array}$ & $\begin{array}{l}\text { Percentage of } \\
\text { Economics } \\
\text { Majors } \\
\end{array}$ \\
\hline New York & 167,634 & 88,922 & 1.89 & 3.99 \\
\hline Alabama & 112,021 & 66,188 & 1.69 & 0.73 \\
\hline Alaska & 68,637 & 74,278 & 0.92 & 1.60 \\
\hline Arizona & 96,507 & 70,798 & 1.36 & 1.54 \\
\hline Arkansas & 82,619 & 60,442 & 1.37 & 1.00 \\
\hline California & 115,328 & 83,096 & 1.39 & 3.20 \\
\hline Colorado & 94,191 & 70,412 & 1.34 & 2.27 \\
\hline Connecticut & 154,854 & 87,807 & 1.76 & 3.32 \\
\hline Delaware & 105,752 & 77,919 & 1.36 & 2.08 \\
\hline District of Columbia & 141,532 & 101,630 & 1.39 & 5.94 \\
\hline Florida & 83,967 & 66,849 & 1.26 & 2.04 \\
\hline Georgia & 103,923 & 71,491 & 1.45 & 1.76 \\
\hline Hawaii & 73,582 & 63,541 & 1.16 & 2.23 \\
\hline Idaho & 99,699 & 59,245 & 1.68 & 0.85 \\
\hline Illinois & 123,524 & 76,843 & 1.61 & 2.55 \\
\hline Indiana & 86,639 & 63,217 & 1.37 & 1.05 \\
\hline Iowa & 72,613 & 60,691 & 1.20 & 1.01 \\
\hline Kansas & 79,169 & 62,324 & 1.27 & 1.14 \\
\hline Kentucky & 97,519 & 61,694 & 1.58 & 1.26 \\
\hline Louisiana & 94,935 & 64,963 & 1.46 & 0.75 \\
\hline Maine & 77,511 & 56,004 & 1.38 & 1.71 \\
\hline Maryland & 101,757 & 79,945 & 1.27 & 2.53 \\
\hline Massachusetts & 131,518 & 81,911 & 1.61 & 2.91 \\
\hline Michigan & 98,343 & 68,596 & 1.43 & 1.41 \\
\hline Minnesota & 109,004 & 70,612 & 1.54 & 2.09 \\
\hline Mississippi & 60,430 & 59,030 & 1.02 & 0.34 \\
\hline Missouri & 115,257 & 64,956 & 1.77 & 1.41 \\
\hline Montana & 53,229 & 51,856 & 1.03 & 0.70 \\
\hline Nebraska & 80,280 & 60,607 & 1.32 & 1.12 \\
\hline Nevada & 85,919 & 70,664 & 1.22 & 2.04 \\
\hline New Hampshire & 81,095 & 67,502 & 1.20 & 1.71 \\
\hline New Jersey & 123,061 & 85,508 & 1.44 & 3.01 \\
\hline New Mexico & 78,734 & 63,826 & 1.23 & 1.35 \\
\hline North Carolina & 98,752 & 66,347 & 1.49 & 1.86 \\
\hline North Dakota & 51,062 & 53,591 & 0.95 & 0.72 \\
\hline Ohio & 97,926 & 67,390 & 1.45 & 1.48 \\
\hline Oklahoma & 67,160 & 60,916 & 1.10 & 1.04 \\
\hline Oregon & 86,159 & 63,966 & 1.35 & 1.87 \\
\hline Pennsylvania & 112,134 & 70,923 & 1.58 & 2.13 \\
\hline Rhode Island & 98,588 & 71,346 & 1.38 & 2.67 \\
\hline South Carolina & 84,253 & 60,597 & 1.39 & 1.69 \\
\hline South Dakota & 70,954 & 56,073 & 1.27 & 1.27 \\
\hline Tennessee & 89,678 & 65,140 & 1.38 & 1.50 \\
\hline Texas & 101,996 & 75,531 & 1.35 & 1.70 \\
\hline Utah & 78,390 & 66,872 & 1.17 & 2.05 \\
\hline Vermont & 72,774 & 57,753 & 1.26 & 1.80 \\
\hline
\end{tabular}




\begin{tabular}{lcccc} 
Virginia & 102,975 & 79,303 & 1.30 & 2.63 \\
Washington & 109,226 & 73,518 & 1.49 & 2.42 \\
West Virginia & 86,800 & 57,691 & 1.50 & 0.67 \\
Wisconsin & 91,018 & 64,766 & 1.41 & 1.87 \\
Wyoming & 109,890 & 57,390 & 1.91 & 0.84 \\
\hline
\end{tabular}


Table 3: Metropolitan Area Group Means for Selected Variables

\begin{tabular}{|c|c|c|c|c|}
\hline Metropolitan Area/Group & $\begin{array}{c}\text { Mean Real } \\
\text { Earnings for } \\
\text { Economics Majors }\end{array}$ & $\begin{array}{l}\text { Mean Real } \\
\text { Earnings for Non- } \\
\text { Economics Majors }\end{array}$ & $\begin{array}{l}\text { Relative Earnings } \\
\text { of Economics } \\
\text { Majors }\end{array}$ & $\begin{array}{c}\text { Percentage of } \\
\text { Economics } \\
\text { Majors } \\
\end{array}$ \\
\hline New York, NY & 170,234 & 96,098 & 1.77 & 4.39 \\
\hline Albany, NY & 69,407 & 69,787 & 0.99 & 2.86 \\
\hline Atlanta, GA & 109,835 & 75,893 & 1.45 & 2.09 \\
\hline Austin, TX & 91,476 & 73,397 & 1.25 & 2.27 \\
\hline Baltimore, MD & 106,327 & 77,994 & 1.36 & 2.37 \\
\hline Boston, MA & 139,070 & 86,900 & 1.60 & 3.16 \\
\hline Buffalo, NY & 80,555 & 63,593 & 1.27 & 1.79 \\
\hline Charlotte, NC & 116,565 & 74,578 & 1.56 & 2.39 \\
\hline Chicago, IL & 124,811 & 80,310 & 1.55 & 2.80 \\
\hline Cincinnati, $\mathrm{OH}$ & 117,239 & 73,301 & 1.60 & 1.50 \\
\hline Cleveland, $\mathrm{OH}$ & 109,104 & 69,949 & 1.56 & 1.80 \\
\hline Columbus, $\mathrm{OH}$ & 103,628 & 68,449 & 1.51 & 1.72 \\
\hline Dallas, TX & 104,292 & 80,522 & 1.30 & 1.93 \\
\hline Detroit, MI & 111,784 & 74,813 & 1.49 & 1.62 \\
\hline Fort Lauderdale, FL & 109,968 & 70,031 & 1.57 & 2.22 \\
\hline Greensboro, NC & 76,980 & 61,188 & 1.26 & 1.89 \\
\hline Hartford, CT & 108,923 & 82,224 & 1.32 & 2.65 \\
\hline Houston, TX & 115,945 & 87,233 & 1.33 & 1.85 \\
\hline Indianapolis, IN & 92,818 & 68,715 & 1.35 & 1.08 \\
\hline Jacksonville, FL & 84,742 & 67,802 & 1.25 & 2.09 \\
\hline Kansas City, MO & 92,949 & 69,764 & 1.33 & 1.72 \\
\hline Las Vegas, NV & 78,905 & 69,810 & 1.13 & 2.09 \\
\hline Los Angeles, CA & 119,102 & 81,323 & 1.46 & 3.43 \\
\hline Louisville, KY & 102,146 & 66,416 & 1.54 & 1.62 \\
\hline Memphis, TN & 108,789 & 72,796 & 1.49 & 1.88 \\
\hline Milwaukee, WI & 93,744 & 72,092 & 1.30 & 2.27 \\
\hline Minneapolis, MN & 106,174 & 74,819 & 1.42 & 2.57 \\
\hline Nashville, TN & 87,948 & 66,768 & 1.32 & 1.72 \\
\hline Norfolk, VA & 98,155 & 66,686 & 1.47 & 1.68 \\
\hline Oklahoma City, OK & 87,896 & 63,742 & 1.38 & 0.95 \\
\hline Orlando, FL & 86,088 & 64,936 & 1.33 & 2.00 \\
\hline Philadelphia, PA & 114,963 & 79,892 & 1.44 & 2.54 \\
\hline Phoenix, AZ & 104,607 & 74,821 & 1.40 & 1.66 \\
\hline Pittsburgh, PA & 114,198 & 68,154 & 1.68 & 2.01 \\
\hline Portland, OR & 95,117 & 68,483 & 1.39 & 2.05 \\
\hline Raleigh, NC & 100,844 & 71,882 & 1.40 & 1.86 \\
\hline Richmond, VA & 115,609 & 74,571 & 1.55 & 2.85 \\
\hline Riverside, CA & 80,209 & 70,776 & 1.13 & 1.52 \\
\hline Rochester, NY & 83,860 & 67,379 & 1.24 & 1.84 \\
\hline
\end{tabular}




\begin{tabular}{lcccc} 
Sacramento, CA & 102,360 & 76,403 & 1.34 & 3.00 \\
St. Louis, MO-IL & 131,379 & 70,960 & 1.85 & 1.79 \\
Salt Lake City, UT & 80,324 & 69,570 & 1.15 & 2.22 \\
San Antonio, TX & 108,107 & 69,821 & 1.55 & 1.36 \\
San Diego, CA & 104,855 & 79,326 & 1.32 & 2.57 \\
San Francisco, CA & 124,265 & 90,611 & 1.37 & 4.18 \\
San Jose, CA & 131,730 & 107,577 & 1.22 & 3.22 \\
Seattle, WA & 112,986 & 79,937 & 1.41 & 2.95 \\
Tampa, FL & 89,101 & 68,797 & 1.30 & 1.58 \\
Washington, DC & 120,312 & 93,512 & 1.29 & 4.07 \\
West Palm Beach, FL & 77,019 & 74,033 & 1.04 & 2.38 \\
Northeast Mid-size Metros & 139,430 & 77,005 & 1.81 & 2.66 \\
Midwest Mid-size Metros & 82,435 & 65,892 & 1.25 & 1.40 \\
South Mid-size Metros & 92,673 & 66,353 & 1.40 & 1.35 \\
West Mid-size Metros & 91,176 & 67,357 & 1.35 & 1.87 \\
Northeast Small Metros & 107,959 & 67,957 & 1.59 & 1.86 \\
Midwest Small Metros & 91,824 & 61,861 & 1.48 & 1.21 \\
South Small Metros & 84,892 & 62,274 & 1.36 & 1.15 \\
West Small Metros & 78,755 & 67,165 & 1.17 & 1.92 \\
Northeast Non-Metro Areas & 90,862 & 60,053 & 1.51 & 1.89 \\
Midwest Non-Metro Areas & 81,100 & 54,238 & 1.50 & 0.92 \\
South Non-Metro Areas & 66,699 & 56,025 & 1.19 & 0.95 \\
West Non-Metro Areas & 75,031 & 57,578 & 1.30 & 1.42 \\
\hline
\end{tabular}


Table 4: State Regression Results

\begin{tabular}{|c|c|c|c|c|c|c|c|c|}
\hline & \multicolumn{4}{|c|}{$\begin{array}{l}\text { Absolute Differences in Log Earnings } \\
\text { among Economics Majors }\end{array}$} & \multicolumn{4}{|c|}{$\begin{array}{l}\text { Differences in Relative Log Earnings for } \\
\text { Economics Majors }\end{array}$} \\
\hline & \multicolumn{2}{|c|}{ No Occ/Ind } & \multicolumn{2}{|c|}{ With Occ/Ind } & \multicolumn{2}{|c|}{ No Occ/Ind } & \multicolumn{2}{|c|}{ With Occ/Ind } \\
\hline & Coeff. & St. Err. & Coeff. & St. Err. & Coeff. & St. Err. & Coeff. & St. Err. \\
\hline New York & N/A & N/A & N/A & N/A & $0.434 * * *$ & $(0.029)$ & $0.237 * * *$ & $(0.025)$ \\
\hline Alabama & $-0.478 * * *$ & $(0.184)$ & $-0.386 * *$ & $(0.157)$ & 0.180 & $(0.171)$ & 0.124 & $(0.147)$ \\
\hline Alaska & $-0.893 * * *$ & $(0.295)$ & $-0.722 * * *$ & $(0.225)$ & -0.237 & $(0.295)$ & -0.336 & $(0.257)$ \\
\hline Arizona & $-0.546 * * *$ & $(0.082)$ & $-0.453 * * *$ & $(0.080)$ & 0.091 & $(0.079)$ & 0.037 & $(0.079)$ \\
\hline Arkansas & $-0.596 * * *$ & $(0.162)$ & $-0.366^{* * *}$ & $(0.138)$ & 0.123 & $(0.169)$ & 0.067 & $(0.149)$ \\
\hline California & $-0.218^{* * *}$ & $(0.035)$ & $-0.186^{* * *}$ & $(0.031)$ & $0.225 * * *$ & $(0.021)$ & $0.152 * * *$ & $(0.020)$ \\
\hline Colorado & $-0.524 * * *$ & $(0.058)$ & $-0.479 * * *$ & $(0.052)$ & $0.147 * * *$ & $(0.053)$ & 0.038 & $(0.052)$ \\
\hline Connecticut & $-0.137 * *$ & $(0.067)$ & $-0.149 * *$ & $(0.061)$ & $0.317 * * *$ & $(0.061)$ & $0.140 * *$ & $(0.056)$ \\
\hline Delaware & $-0.374 * *$ & $(0.177)$ & $-0.500 * * *$ & $(0.177)$ & 0.084 & $(0.174)$ & -0.061 & $(0.166)$ \\
\hline Dist. of Columbia & -0.113 & $(0.072)$ & -0.070 & $(0.06$ & $0.164 * * *$ & $(0.063)$ & 0.066 & $(0.058)$ \\
\hline Florida & $-0.606^{* * *}$ & $(0.050)$ & $-0.482 * * *$ & $(0.04$ & 0.044 & $(0.041)$ & 0.043 & $(0.036)$ \\
\hline Georgia & $-0.480^{* * *}$ & $(0.074)$ & $-0.438^{* * *}$ & $(0.06$ & $0.128^{*}$ & $(0.069)$ & 0.047 & $(0.063)$ \\
\hline Hawaii & $-0.589 * * *$ & $(0.133)$ & $-0.447 * * *$ & $(0.11$ & 0.049 & $(0.132)$ & 0.088 & $(0.116)$ \\
\hline Idaho & $-0.507 * * *$ & $(0.174)$ & -0.269 & $(0.165)$ & $0.325^{* *}$ & $(0.157)$ & $0.326^{* *}$ & $(0.154)$ \\
\hline Illinois & $-0.248 * * *$ & $(0.044)$ & $-0.203^{* * *}$ & $(0.04$ & $0.316^{* * *}$ & $(0.035)$ & $0.217 * * *$ & $(0.032)$ \\
\hline Indiana & $-0.575^{* * *}$ & $(0.093)$ & $-0.521 * * *$ & $(0.08$ & $0.163^{*}$ & $(0.0$ & 0.108 & $(0.083)$ \\
\hline Iowa & $-0.835^{* * *}$ & $(0.133)$ & $-0.715^{* * *}$ & $(0.113)$ & -0.108 & $(0.133)$ & -0.099 & $(0.113)$ \\
\hline Kansas & $-0.743 * * *$ & $(0.141)$ & $-0.669^{* * *}$ & $(0.13$ & -0.075 & $(0.136)$ & -0.129 & $(0.123)$ \\
\hline Kentucky & $-0.456^{* * *}$ & $(0.100)$ & $-0.511 * * *$ & $(0.091)$ & $0.269 * * *$ & $(0.092)$ & 0.110 & $(0.092)$ \\
\hline Louisiana & $-0.697 * * *$ & $(0.152)$ & $-0.516^{* * *}$ & $(0.138)$ & -0.067 & $(0.152)$ & 0.013 & $(0.139)$ \\
\hline Maine & $-0.742 * * *$ & $(0.153)$ & $-0.584 * * *$ & $(0.13$ & 0.085 & $(0.153)$ & 0.099 & $(0.154)$ \\
\hline Maryland & $-0.391 * * *$ & $(0.058)$ & $-0.300^{* * *}$ & $(0.054)$ & 0.088 & $(0.055)$ & 0.037 & $(0.052)$ \\
\hline Massachusetts & $-0.251 * * *$ & $(0.051)$ & $-0.201 * * *$ & $(0.047)$ & $0.277 * * *$ & $(0.043)$ & $0.183^{* * *}$ & $(0.041)$ \\
\hline Michigan & $-0.538 * * *$ & $(0.075)$ & $-0.459 * * *$ & $(0.058)$ & $0.139^{*}$ & $(0.072)$ & $0.111^{* *}$ & $(0.057)$ \\
\hline Minnesota & $-0.345^{* * *}$ & $(0.066)$ & $-0.328 * * *$ & $(0.063)$ & $0.282 * * *$ & $(0.062)$ & $0.153^{* * *}$ & $(0.059)$ \\
\hline Mississippi & $-0.744 * * *$ & $(0.185)$ & $-0.622 * * *$ & $(0.201)$ & -0.007 & $(0.186)$ & -0.093 & $(0.185)$ \\
\hline Missouri & $-0.439 * * *$ & $(0.076)$ & $-0.402 * * *$ & $(0.067)$ & $0.258^{* * *}$ & $(0.071)$ & $0.196^{* * *}$ & $(0.064)$ \\
\hline Montana & $-0.990 * * *$ & $(0.215)$ & $-0.685^{* * *}$ & $(0.194)$ & -0.064 & $(0.233)$ & 0.038 & $(0.206)$ \\
\hline Nebraska & $-0.637 * * *$ & $(0.195)$ & $-0.575^{* * *}$ & $(0.129)$ & 0.082 & $(0.206)$ & 0.033 & $(0.134)$ \\
\hline Nevada & $-0.510 * * *$ & $(0.106)$ & $-0.336^{* * *}$ & $(0.084)$ & 0.072 & $(0.100)$ & 0.108 & $(0.093)$ \\
\hline New Hampshire & $-0.999 * * *$ & $(0.330)$ & $-0.848 * * *$ & $(0.321)$ & -0.288 & $(0.334)$ & -0.331 & $(0.314)$ \\
\hline New Jersey & $-0.237 * * *$ & $(0.047)$ & $-0.209^{* * *}$ & $(0.042)$ & $0.207 * * *$ & $(0.039)$ & $0.127^{* * *}$ & $(0.035)$ \\
\hline New Mexico & $-0.658 * * *$ & $(0.099)$ & $-0.570 * * *$ & $(0.083)$ & 0.039 & $(0.096)$ & 0.017 & $(0.082)$ \\
\hline North Carolina & $-0.510 * * *$ & $(0.059)$ & $-0.454 * * *$ & $(0.054)$ & $0.145^{* * *}$ & $(0.052)$ & $0.091^{*}$ & $(0.050)$ \\
\hline North Dakota & $-0.715^{* * *}$ & $(0.252)$ & $-0.762 * *$ & $(0.317)$ & 0.148 & $(0.186)$ & -0.082 & $(0.210)$ \\
\hline Ohio & $-0.579 * * *$ & $(0.065)$ & $-0.489 * * *$ & $(0.057)$ & 0.095 & $(0.060)$ & $0.091 *$ & $(0.052)$ \\
\hline Oklahoma & $-0.788 * * *$ & $(0.135)$ & $-0.606^{* * *}$ & $(0.109)$ & -0.049 & $(0.140)$ & -0.054 & $(0.115)$ \\
\hline Oregon & $-0.610^{* * *}$ & $(0.086)$ & $-0.492 * * *$ & $(0.071)$ & 0.111 & $(0.083)$ & 0.086 & $(0.067)$ \\
\hline Pennsylvania & $-0.429^{* * *}$ & $(0.052)$ & $-0.367 * * *$ & $(0.046)$ & $0.230 * * *$ & $(0.045)$ & $0.149^{* * *}$ & $(0.041)$ \\
\hline Rhode Island & $-0.561 * * *$ & $(0.106)$ & $-0.489 * * *$ & $(0.084)$ & 0.101 & $(0.105)$ & 0.041 & $(0.092)$ \\
\hline South Carolina & $-0.602 * * *$ & $(0.074)$ & $-0.518 * * *$ & $(0.074)$ & $0.117 *$ & $(0.069)$ & 0.076 & $(0.062)$ \\
\hline South Dakota & $-0.818^{* * *}$ & $(0.270)$ & $-0.521^{* * *}$ & $(0.200)$ & 0.148 & $(0.211)$ & 0.216 & $(0.187)$ \\
\hline Tennessee & $-0.762 * * *$ & $(0.098)$ & $-0.683 * * *$ & $(0.094)$ & -0.054 & $(0.096)$ & -0.099 & $(0.089)$ \\
\hline Texas & $-0.397 * * *$ & $(0.044)$ & $-0.359 * * *$ & $(0.039)$ & $0.150 * * *$ & $(0.034)$ & $0.093 * * *$ & $(0.031)$ \\
\hline Utah & $-0.758 * * *$ & $(0.098)$ & $-0.651 * * *$ & $(0.102)$ & -0.078 & $(0.093)$ & -0.116 & $(0.092)$ \\
\hline Vermont & $-0.841 * * *$ & $(0.167)$ & $-0.625^{* * *}$ & $(0.153)$ & -0.085 & $(0.162)$ & -0.002 & $(0.148)$ \\
\hline Virginia & $-0.358 * * *$ & $(0.048)$ & $-0.313^{* * *}$ & $(0.043)$ & $0.139 * * *$ & $(0.040)$ & 0.041 & $(0.037)$ \\
\hline Washington & $-0.308 * * *$ & $(0.056)$ & $-0.254 * * *$ & $(0.052)$ & $0.282 * * *$ & $(0.050)$ & $0.213 * * *$ & $(0.045)$ \\
\hline
\end{tabular}




\begin{tabular}{lllllllll} 
West Virginia & $-0.454^{* *}$ & $(0.198)$ & -0.285 & $(0.232)$ & 0.308 & $(0.253)$ & 0.380 & $(0.248)$ \\
Wisconsin & $-0.542^{* * *}$ & $(0.080)$ & $-0.470^{* * *}$ & $(0.069)$ & $0.158^{* *}$ & $(0.074)$ & 0.093 & $(0.075)$ \\
Wyoming & -0.249 & $(0.261)$ & -0.066 & $(0.258)$ & 0.515 & $(0.314)$ & 0.142 & $(0.251)$ \\
\hline
\end{tabular}

Notes: New York is the omitted state in the absolute differences regressions. All regressions include individual controls for age, sex, race, Hispanic origin, foreign born status, and highest degree completed. The second and fourth regressions also include dummies for 83 occupation and 16 industries. Robust standard errors in parentheses. *Significant at $10 \% ; * *$ Significant at $5 \% ; * *$ Significant at $1 \%$. 
Table 5: Metropolitan Area/Group Regression Results

\begin{tabular}{|c|c|c|c|c|c|c|c|c|}
\hline & \multicolumn{4}{|c|}{$\begin{array}{c}\text { Absolute Differences in Log Earnings among } \\
\text { Economics Majors }\end{array}$} & \multicolumn{4}{|c|}{$\begin{array}{l}\text { Differences in Relative Log Earnings for } \\
\text { Economics Majors }\end{array}$} \\
\hline & \multicolumn{2}{|c|}{ No Occ/Ind } & \multicolumn{2}{|c|}{ With Occ/Ind } & \multicolumn{2}{|c|}{ No Occ/Ind } & \multicolumn{2}{|c|}{ With Occ/Ind } \\
\hline & Coeff. & St. Err. & Coeff. & St. Err. & Coeff. & St. Err. & Coeff. & St. Err. \\
\hline New York, NY & $\mathrm{N} / \mathrm{A}$ & N/A & $\mathrm{N} / \mathrm{A}$ & N/A & $0.370 * * *$ & $(0.026)$ & $0.202 * * *$ & $(0.023)$ \\
\hline Albany, NY & $-0.767 * * *$ & $(0.130)$ & $-0.515 * * *$ & $(0.104)$ & -0.071 & $(0.112)$ & 0.006 & $(0.100)$ \\
\hline Atlanta, GA & $-0.494 * * *$ & $(0.085)$ & $-0.449 * * *$ & $(0.078)$ & 0.122 & $(0.081)$ & 0.044 & $(0.075)$ \\
\hline Austin, TX & $-0.390 * * *$ & $(0.070)$ & $-0.364 * * *$ & $(0.069)$ & $0.242 * * *$ & $(0.068)$ & $0.147 * *$ & $(0.067)$ \\
\hline Baltimore, MD & $-0.453 * * *$ & $(0.074)$ & $-0.348 * * *$ & $(0.070)$ & 0.095 & $(0.071)$ & 0.026 & $(0.068)$ \\
\hline Boston, MA & $-0.238 * * *$ & $(0.054)$ & $-0.205^{* * *}$ & $(0.051)$ & $0.285 * * *$ & $(0.047)$ & $0.170 * * *$ & $(0.046)$ \\
\hline Buffalo, NY & $-0.622 * * *$ & $(0.109)$ & $-0.507 * * *$ & $(0.114)$ & $0.210 * *$ & $(0.104)$ & $0.202 *$ & $(0.109)$ \\
\hline Charlotte, NC & $-0.428 * * *$ & $(0.097)$ & $-0.409 * * *$ & $(0.081)$ & $0.205 * *$ & $(0.094)$ & 0.132 & $(0.085)$ \\
\hline Chicago, IL & $-0.248 * * *$ & $(0.042)$ & $-0.203 * * *$ & $(0.039)$ & $0.325 * * *$ & $(0.034)$ & $0.219 * * *$ & $(0.033)$ \\
\hline Cincinnati, $\mathrm{OH}$ & $-0.415 * * *$ & $(0.107)$ & $-0.414 * * *$ & $(0.096)$ & $0.253 * *$ & $(0.111)$ & 0.121 & $(0.102)$ \\
\hline Cleveland, $\mathrm{OH}$ & $-0.564 * * *$ & $(0.150)$ & $-0.473 * * *$ & $(0.123)$ & 0.133 & $(0.149)$ & 0.121 & $(0.115)$ \\
\hline Columbus, $\mathrm{OH}$ & $-0.605 * * *$ & $(0.109)$ & $-0.509 * * *$ & $(0.109)$ & 0.081 & $(0.108)$ & 0.063 & $(0.110)$ \\
\hline Dallas, TX & $-0.432 * * *$ & $(0.058)$ & $-0.392 * * *$ & $(0.053)$ & $0.110^{* *}$ & $(0.052)$ & 0.046 & $(0.048)$ \\
\hline Detroit, MI & $-0.491 * * *$ & $(0.101)$ & $-0.430 * * *$ & $(0.080)$ & $0.209 *$ & $(0.107)$ & $0.158^{*}$ & $(0.090)$ \\
\hline Fort Lauderdale, FL & $-0.483 * * *$ & $(0.119)$ & $-0.329 * * *$ & $(0.109)$ & 0.194 & $(0.120)$ & $0.224 * *$ & $(0.109)$ \\
\hline Greensboro, NC & $-0.810^{* * *}$ & $(0.141)$ & $-0.743 * * *$ & $(0.141)$ & -0.066 & $(0.141)$ & -0.181 & $(0.139)$ \\
\hline Hartford, CT & $-0.309 * * *$ & $(0.103)$ & $-0.230 * *$ & $(0.093)$ & $0.226^{* *}$ & $(0.097)$ & 0.127 & $(0.089)$ \\
\hline Houston, TX & $-0.276^{* * *}$ & $(0.066)$ & $-0.266^{* * *}$ & $(0.061)$ & $0.226 * * *$ & $(0.063)$ & $0.136^{* *}$ & $(0.058)$ \\
\hline Indianapolis, IN & $-0.684 * * *$ & $(0.170)$ & $-0.677 * * *$ & $(0.157)$ & 0.031 & $(0.165)$ & -0.084 & $(0.161)$ \\
\hline Jacksonville, FL & $-0.472 * * *$ & $(0.111)$ & $-0.406^{* * *}$ & $(0.103)$ & $0.202^{*}$ & $(0.108)$ & 0.172 & $(0.106)$ \\
\hline Kansas City, MO & $-0.680 * * *$ & $(0.116)$ & $-0.637 * * *$ & $(0.107)$ & -0.037 & $(0.111)$ & -0.129 & $(0.100)$ \\
\hline Las Vegas, NV & $-0.610^{* * *}$ & $(0.114)$ & $-0.414 * * *$ & $(0.088)$ & -0.003 & $(0.106)$ & 0.026 & $(0.099)$ \\
\hline Los Angeles, CA & $-0.241 * * *$ & $(0.041)$ & $-0.206^{* * *}$ & $(0.037)$ & $0.246 * * *$ & $(0.032)$ & $0.175^{* * *}$ & $(0.030)$ \\
\hline Louisville, KY & $-0.491 * * *$ & $(0.135)$ & $-0.405 * * *$ & $(0.105)$ & $0.295 * *$ & $(0.135)$ & $0.193^{*}$ & $(0.115)$ \\
\hline Memphis, TN & $-0.950 * * *$ & $(0.274)$ & $-0.908 * * *$ & $(0.263)$ & -0.273 & $(0.272)$ & -0.349 & $(0.252)$ \\
\hline Milwaukee, WI & $-0.553 * * *$ & $(0.125)$ & $-0.520 * * *$ & $(0.123)$ & 0.071 & $(0.109)$ & 0.005 & $(0.129)$ \\
\hline Minneapolis, MN & $-0.408 * * *$ & $(0.069)$ & $-0.376^{* * *}$ & $(0.066)$ & $0.230 * * *$ & $(0.065)$ & 0.102 & $(0.063)$ \\
\hline Nashville, TN & $-0.726^{* * *}$ & $(0.123)$ & $-0.721 * * *$ & $(0.134)$ & 0.008 & $(0.118)$ & -0.122 & $(0.125)$ \\
\hline Norfolk, VA & $-0.587 * * *$ & $(0.118)$ & $-0.472 * * *$ & $(0.109)$ & 0.112 & $(0.115)$ & 0.117 & $(0.108)$ \\
\hline Oklahoma City, OK & $-0.811^{* * *}$ & $(0.212)$ & $-0.732 * * *$ & $(0.164)$ & -0.067 & $(0.208)$ & -0.089 & $(0.177)$ \\
\hline Orlando, FL & $-0.692 * * *$ & $(0.115)$ & $-0.601 * * *$ & $(0.116)$ & 0.030 & $(0.113)$ & 0.016 & $(0.111)$ \\
\hline Philadelphia, PA & $-0.393 * * *$ & $(0.060)$ & $-0.341 * * *$ & $(0.054)$ & $0.182 * * *$ & $(0.055)$ & $0.110^{* *}$ & $(0.050)$ \\
\hline Phoenix, AZ & $-0.484 * * *$ & $(0.091)$ & $-0.387 * * *$ & $(0.085)$ & 0.146 & $(0.091)$ & 0.112 & $(0.088)$ \\
\hline Pittsburgh, PA & $-0.550 * * *$ & $(0.101)$ & $-0.429 * * *$ & $(0.084)$ & $0.226^{* *}$ & $(0.101)$ & $0.198 * *$ & $(0.082)$ \\
\hline Portland, OR & $-0.563 * * *$ & $(0.086)$ & $-0.458 * * *$ & $(0.076)$ & $0.169 * *$ & $(0.082)$ & 0.108 & $(0.069)$ \\
\hline Raleigh, NC & $-0.578 * * *$ & $(0.085)$ & $-0.473 * * *$ & $(0.078)$ & 0.118 & $(0.086)$ & 0.140 & $(0.086)$ \\
\hline Richmond, VA & $-0.360 * * *$ & $(0.092)$ & $-0.421 * * *$ & $(0.089)$ & $0.255 * * *$ & $(0.089)$ & 0.068 & $(0.088)$ \\
\hline Riverside, CA & $-0.665^{* * *}$ & $(0.150)$ & $-0.405 * * *$ & $(0.112)$ & -0.129 & $(0.146)$ & 0.033 & $(0.111)$ \\
\hline Rochester, NY & $-0.699 * * *$ & $(0.112)$ & $-0.626^{* * *}$ & $(0.093)$ & 0.031 & $(0.109)$ & -0.048 & $(0.097)$ \\
\hline Sacramento, CA & $-0.398 * * *$ & $(0.090)$ & $-0.330 * * *$ & $(0.076)$ & 0.127 & $(0.088)$ & 0.085 & $(0.072)$ \\
\hline St. Louis, MO-IL & $-0.435 * * *$ & $(0.098)$ & $-0.380 * * *$ & $(0.089)$ & $0.266^{* * *}$ & $(0.097)$ & $0.217 * *$ & $(0.090)$ \\
\hline Salt Lake City, UT & $-0.699 * * *$ & $(0.084)$ & $-0.578 * * *$ & $(0.089)$ & -0.004 & $(0.085)$ & -0.030 & $(0.084)$ \\
\hline San Antonio, TX & $-0.639 * * *$ & $(0.132)$ & $-0.615 * * *$ & $(0.138)$ & 0.042 & $(0.136)$ & -0.014 & $(0.143)$ \\
\hline San Diego, CA & $-0.418^{* * *}$ & $(0.073)$ & $-0.328 * * *$ & $(0.066)$ & $0.181 * * *$ & $(0.069)$ & $0.144 * *$ & $(0.065)$ \\
\hline San Francisco, CA & $-0.141 * * *$ & $(0.052)$ & $-0.114 * *$ & $(0.048)$ & $0.270 * * *$ & $(0.045)$ & $0.152 * * *$ & $(0.042)$ \\
\hline San Jose, CA & -0.069 & $(0.065)$ & $-0.114 *$ & $(0.059)$ & $0.226 * * *$ & $(0.063)$ & $0.119 * *$ & $(0.057)$ \\
\hline Seattle, WA & $-0.285^{* * *}$ & $(0.064)$ & $-0.269 * * *$ & $(0.061)$ & $0.280 * * *$ & $(0.060)$ & $0.168^{* * *}$ & $(0.055)$ \\
\hline Tampa, FL & $-0.653 * * *$ & $(0.110)$ & $-0.521 * * *$ & $(0.093)$ & 0.071 & $(0.108)$ & 0.048 & $(0.093)$ \\
\hline
\end{tabular}




\begin{tabular}{lllllllll} 
Washington, DC & $-0.284^{* * *}$ & $(0.049)$ & $-0.207^{* * *}$ & $(0.044)$ & $0.116^{* * *}$ & $(0.043)$ & 0.027 & $(0.040)$ \\
West Palm Beach, FL & $-0.801^{* * *}$ & $(0.149)$ & $-0.657^{* * *}$ & $(0.148)$ & -0.136 & $(0.153)$ & -0.124 & $(0.129)$ \\
Northeast Mid Metros & $-0.258^{* * *}$ & $(0.055)$ & $-0.219^{* * *}$ & $(0.050)$ & $0.377^{* * *}$ & $(0.049)$ & $0.241^{* * *}$ & $(0.045)$ \\
Midwest Mid Metros & $-0.692^{* * *}$ & $(0.075)$ & $-0.578^{* * *}$ & $(0.057)$ & 0.046 & $(0.069)$ & 0.021 & $(0.054)$ \\
South Mid Metros & $-0.644^{* * *}$ & $(0.062)$ & $-0.560^{* * *}$ & $(0.058)$ & 0.071 & $(0.055)$ & 0.024 & $(0.051)$ \\
West Mid Metros & $-0.525^{* * *}$ & $(0.062)$ & $-0.400^{* * *}$ & $(0.057)$ & $0.166^{* * *}$ & $(0.056)$ & $0.144^{* * *}$ & $(0.053)$ \\
Northeast Small Metros & $-0.532^{* * *}$ & $(0.071)$ & $-0.413^{* * *}$ & $(0.065)$ & $0.199^{* * *}$ & $(0.066)$ & $0.125^{* *}$ & $(0.061)$ \\
Midwest Small Metros & $-0.655^{* * *}$ & $(0.071)$ & $-0.538^{* * *}$ & $(0.062)$ & $0.133^{* *}$ & $(0.066)$ & $0.105^{*}$ & $(0.059)$ \\
South Small Metros & $-0.628^{* * *}$ & $(0.059)$ & $-0.466^{* * *}$ & $(0.052)$ & $0.154^{* * *}$ & $(0.052)$ & $0.158^{* * *}$ & $(0.049)$ \\
West Small Metros & $-0.707^{* * *}$ & $(0.078)$ & $-0.591^{* * *}$ & $(0.070)$ & 0.012 & $(0.075)$ & -0.046 & $(0.071)$ \\
Northeast Non-Metros & $-0.777^{* * *}$ & $(0.086)$ & $-0.635^{* * *}$ & $(0.078)$ & 0.091 & $(0.086)$ & 0.012 & $(0.080)$ \\
Midwest Non-Metro & $-0.806^{* * *}$ & $(0.084)$ & $-0.619^{* * *}$ & $(0.071)$ & $0.141^{*}$ & $(0.078)$ & $0.158^{* *}$ & $(0.065)$ \\
South Non-Metros & $-0.941^{* * *}$ & $(0.081)$ & $-0.741^{* * *}$ & $(0.070)$ & -0.069 & $(0.074)$ & -0.049 & $(0.065)$ \\
West Non-Metros & $-0.873^{* * *}$ & $(0.090)$ & $-0.617^{* * *}$ & $(0.087)$ & 0.037 & $(0.091)$ & 0.080 & $(0.081)$ \\
\hline
\end{tabular}

Notes: New York is the omitted metropolitan area in the absolute differences regressions. All regressions include individual controls for age, sex, race, Hispanic origin, foreign born status, and highest degree completed. The second and fourth regressions also include dummies for 83 occupation and 16 industries. Robust standard errors in parentheses.

*Significant at $10 \% ; * *$ Significant at $5 \% ; * *$ Significant at $1 \%$. 